\title{
UPAYA MENINGKATKAN KEMAMPUAN PENALARAN MATEMATIS SISWA SMK MELALUI PEMBELAJARAN KOOPERATIF TIPE NUMBERED HEAD TOGETHER
}

\author{
Erma Monariska \\ Universitas Suryakancana \\ ermamonariska@unsur.ac.id \\ ermamonariska@gmail.com
}

\begin{abstract}
ABSTRAK
Latar belakang masalah pada penelitian ini adalah kemampuan penalaran matematis siswa SMK yang masih rendah. Dengan melihat dari berbagai model pembelajaran, model pembelajaran kooperatif tipe Numbered Head Together (NHT) dapat meningkatkan kemampuan penalaran matematis siswa. Tujuan dari penelitian ini adalah: untuk mengetahui apakah pembelajaran kooperatif tipe $N H T$ dapat meningkatkan penalaran matematis siswa SMK; untuk mengetahui aktivitas siswa SMK selama pembelajaran dengan menggunakan pembelajaran kooperatif tipe NHT; dan untuk mengetahui sikap siswa SMK terhadap pembelajaran matematika dengan menggunakan pembelajaran kooperatif tipe $N H T$. Metode penelitian yang digunakan adalah Penelitian Tindakan Kelas (PTK) yang merupakan bentuk penelitian reflektif yang dilakukan oleh guru sendiri yang hasilnya dapat dimanfaatkan sebagai alat untuk pengembangan dan perbaikan pembelajaran. Prosedur PTK dimulai dengan perencanaan tindakan, pelaksanaan tindakan, observasi dan refleksi tindakan. Subjek penelitian adalah siswa kelas XI Administrasi Perkantoran (AP) SMK PGRI 2 Cianjur. Instrumen yang digunakan dalam penelitian ini berupa tes, non tes (skala sikap, jurnal, lembar observasi) dan instrumen untuk membantu pelaksanaan tindakan (silabus, RPP, LKS). Berdasarkan hasil analisis, diketahui bahwa pembelajaran menggunakan model pembelajaran kooperatif tipe $N H T$ dapat meningkatkan penalaran matematis siswa. Ini sejalan dengan adanya peningkatan aktivitas siswa dan guru dalam proses pembelajaran melalui pembelajaran kooperatif tipe $N H T$.
\end{abstract}

Kata Kunci : Model Pembelajaran Kooperatif Tipe NHT, Kemampuan Penalaran Matematis

\begin{abstract}
The background of the problem in this study is the mathematical reasoning ability of vocational students who are still low. By looking at various learning models, the cooperative learning model Numbered Head Together (NHT) can improve students' mathematical reasoning abilities. The objectives of this study are: to determine whether NHT type cooperative learning can improve the mathematical reasoning of vocational students; to find out the activities of vocational students during learning using NHT type cooperative learning; and to find out the attitudes of Vocational students towards learning mathematics using NHT type cooperative learning. The research method used is Classroom Action Research (CAR) which is a form of reflective research conducted by the teacher himself whose results can be used as a tool for the development and improvement of learning. The PTK procedure begins with action planning, implementing actions, observing and reflecting actions. The research subjects were students of Class XI Office Administration (AP) at SMK PGRI 2 Cianjur. The instruments used in this study were tests, non tests (attitude scale, journals, observation sheets) and instruments to help implement actions (syllabus, RPP, LKS).
\end{abstract}


Based on the results of the analysis, it is known that learning using the NHT cooperative learning model can improve students' mathematical reasoning. This is in line with the increasing activity of students and teachers in the learning process through NHT type cooperative learning.

Keywords : Cooperative Learning Model NHT Type, Mathematical Reasoning Ability

\section{PENDAHULUAN}

Pendidikan merupakan suatu proses untuk mengembangkan semua aspek kepribadian manusia, yang mencakup pengetahuan, nilai dan sikap, serta keterampilan. Sadulloh (2007: 57) mengatakan bahwa pendidikan digulirkan untuk mencapai kepribadian individu yang lebih baik. Pendidikan juga merupakan salah satu bagian dari proses pembangunan bangsa yang dilaksanakan secara sadar dan terencana supaya peserta didik dapat mengembangkan potensi dirinya. Proses pendidikan diharapkan dapat memberikan suasana yang kondusif, sehingga peserta didik dapat memberikan sejumlah keterampilan bagi Bangsa dan Negara.

Hal ini sejalan dengan makna pendidikan dalam Undang-undang Sistem Pendidikan Nasional (UU SISDIKNAS) No. 20 Tahun 2003 Pasal 1 ayat 1, yaitu:

Pendidikan adalah usaha sadar dan terencana untuk mewujudkan suasana belajar dan proses pembelajaran agar peserta didik secara aktif mengembangkan potensinya untuk memiliki kekuatan spiritual, keagamaan, pengendalian diri, kepribadian, akhlak mulia, serta keterampilan yang diperlukan dirinya, masyarakat, bangsa dan Negara.

Berdasarkan makna di atas maka harus dipersiapkan suatu pembelajaran yang menunjang terhadap kehidupan yang sedang ditempuh. Untuk menjadikan anak sebagai aset bangsa yang berkualitas hendaknya proses pembelajaran mampu meningkatkan kemampuan bersikap dan berpikir anak sehingga menjadi lebih kreatif dan mempunyai wawasan yang luas.

Kegiatan utama dalam pendidikan di sekolah adalah proses belajar mengajar. Proses belajar mengajar pada dasarnya merupakan proses interaksi antara dua unsur, yaitu siswa yang sedang belajar dan guru yang mengajar, dan berlangsung dalam suatu ikatan untuk mencapai tujuan pembelajaran yang telah ditetapkan.

Salah satu mata pelajaran yang penting adalah matematika. Menurut Suradi (Darma et al, 2013: 2) pada umumnya masalah pendidikan matematika selalu menjadi sorotan karena masih rendahnya prestasi belajar siswa pada bidang studi tersebut. Oleh karena itu, peningkatan mutu pendidikan matematika selalu menjadi topik menarik untuk didiskusikan. Berbagai upaya telah dilakukan, namun hasil yang diperoleh masih belum optimal sesuai yang diharapkan. Hal ini disebabkan karena masih banyak siswa yang 
kurang menyukai pelajaran matematika. Ada yang menganggap bahwa matematika sulit dipelajari, bahkan ada siswa merasa tegang jika tiba waktunya untuk belajar matematika di sekolah. Banyak siswa menganggap bahwa matematika tidaklah lebih dari sekedar berhitung dan bermain dengan rumus dan angka-angka. Umumnya pelajaran matematika di sekolah menjadi pelajaran yang menakutkan bagi siswa

Salah satu tujuan diberikannya mata pelajaran matematika adalah agar siswa mampu melakukan penalaran. Selanjutnya, Putri (2013 : 19) mengatakan bahwa kompetensi yang diharapkan muncul sebagai dampak dari pembelajaran matematika dan memberi peran yang besar dalam mencapai hasil belajar matematika yang optimal yaitu kemampuan penalaran matematis.

Menurut Shurter dan Pierce (Dewi, 2009:25) mengatakan bahwa penalaran adalah proses pencarian kesimpulan logis berdasarkan fakta dan sumber relevan. Sukirwan (Putri, 2013: 20) menyatakan bahwa kemampuan penalaran merupakan bagian terpenting dalam matematika. Hal ini sejalan dengan Depdiknas (Putri, 2013: 20) yang menyatakan bahwa materi matematika dan penalaran matematis merupakan suatu hal yang tidak dapat dipisahkan, artinya materi matematika dipahami melalui penalaran kemudian dipahami dan dilatihkan melalui belajar materi matematika. Dengan kata lain, belajar matematika tidak terlepas dari aktivitas bernalar.

Rendahnya kemampuan penalaran matematis siswa akan mempengaruhi kualitas belajar siswa, yang berdampak pula pada rendahnya prestasi siswa di sekolah. Hal ini terlihat dari hasil pembelajaran siswa yang tersirat dalam hasil penelitian yang dilakukan oleh Sumarmo (Putri, 2013: 20) yang menyatakan bahwa skor kemampuan siswa dalam pemahaman dan penalaran masih rendah. Hal ini juga terlihat dari prestasi siswa dalam belajar matematika memberikan hasil yang kurang menggembirakan, yang ditunjukkan dengan rendahnya prestasi siswa Indonesia dalam matematika yang diungkapkan oleh hasil tes PISA 2006 yang menunjukkan bahwa Indonesia berada pada peringkat 52 dari 57 negara, Kusumah (Putri, 2013: 20). Merujuk dari penelitian di atas, pembelajaran matematika yang mengarah kepada meningkatnya kemampuan penalaran matematis sudah semestinya diupayakan dan diimplementasikan (Putri, 2013: 20).

Berdasarkan pernyataan sebelumnya dapat dilihat bahwa kemampuan penalaran di Indonesia hanya mencapai $17 \%$ dan masih jauh di bawah rata-rata. Mencermati begitu pentingnya kemampuan penalaran pada pembelajaran matematika maka siswa dituntut untuk memiliki kemampuan ini. Karena matematika pada dasarnya suatu alat untuk mengembangkan cara berpikir, oleh karena itu penalaran matematika diperlukan untuk 
menentukan apakah sebuah argumen matematika benar atau salah dan dipakai untuk membangun suatu argumen matematika pada proses belajar. Penalaran matematika tidak hanya penting untuk melakukan pembuktian atau pemeriksaan program, tetapi juga untuk inferensi dalam suatu sistem kecerdasan buatan. Karin Brodie menyatakan bahwa, "Mathematical reasoning is reasoning about and with the object of mathematics." Pernyataan tersebut dapat diartikan bahwa penalaran matematis adalah penalaran mengenai objek matematika. Objek matematika dalam hal ini adalah cabang-cabang matematika yang dipelajari seperti statistik, aljabar, geometri, dan sebagainya.

Oleh karena itu, untuk meningkatkan kemampuan penalaran matematis siswa, guru sebagai tenaga pendidik hendaknya menggunakan cara mengajar yang dapat membuat siswa aktif dalam proses pembelajaran. Salah satu model pembelajaran yang melibatkan peran siswa secara aktif adalah model pembelajaran kooperatif. Model pembelajaran kooperatif sangat cocok diterapkan pada pembelajaran matematika karena dalam mempelajari matematika tidak cukup hanya mengetahui dan menghafal konsep-konsep matematika tetapi juga dibutuhkan suatu pemahaman serta kemampuan menyelesaikan persoalan matematika dengan baik dan benar. Melalui model pembelajaran ini siswa dapat mengemukakan pemikirannya, saling bertukar pendapat, saling bekerja sama jika ada teman dalam kelompoknya yang mengalami kesulitan. Hal ini dapat meningkatkan motivasi siswa untuk mengkaji dan menguasai materi pelajaran matematika melalui kegiatan bernalar sehingga nantinya akan meningkatkan prestasi belajar matematika siswa.

Tipe NHT merupakan salah satu model pembelajaran kooperatif yang merupakan strategi pembelajaran yang mengutamakan adanya kerjasama antar siswa yang dibagi ke dalam beberapa kelompok-kelompok kecil dimana setiap siswa diberi nomor dan diarahkan untuk mempelajari materi pelajaran yang telah ditentukan, kemudian secara acak guru memanggil nomor dari siswa tersebut.

Tujuan dibentuknya kelompok kooperatif adalah untuk memberikan kesempatan kepada siswa agar dapat terlibat secara aktif dalam proses berfikir dan dalam kegiatankegiatan belajar. Dalam hal ini sebagian besar aktivitas pembelajaran berpusat pada siswa. Oleh karena itu diperlukan suatu penelitian untuk mengukur sekaligus melihat sejauh mana model pembelajaran kooperatif tipe NHT dapat meningkatkan kemampuan penalaran matematis siswa.

Berdasarkan pemikiran di atas, maka peneliti tertarik untuk melakukan suatu penelitian yang berjudul : "UPAYA MENINGKATKAN KEMAMPUAN PENALARAN 
MATEMATIS SISWA SMK MELALUI PEMBELAJARAN KOOPERATIF TIPE NUMBERED HEAD TOGETHER".

\section{METODE PENELITIAN}

Metode yang digunakan dalam penelitian ini adalah Penelitian Tindakan Kelas (PTK), yaitu suatu bentuk kajian yang bersifat refrektif yang dilakukan guru terhadap kurikulum, pengembangan sekolah, dan pengembangan keahlian mengajar. Menurut Aqib (2007:13), PTK merupakan suatu pencermatan terhadap kegiatan yang sengaja dimunculkan dan terjadi dalam sebuah kelas. Arikunto (2010:2) mendefinisikan PTK berdasarkan kata pembentuknya, yaitu penelitian, tindakan, dan kelas.

Tujuan PTK (Arikunto, 2010: 60) antara lain sebagai berikut:

a. Meningkatkan mutu isi, masukan, proses, serta hasil pendidikan dan pembelajaran di sekolah.

b. Membantu guru dan tenaga kependidikan lainnya mengatasi masalah pembelajaran dan pendidikan di dalam dan luar kelas.

c. Meningkatkan sikap profesional pendidik dan tenaga kependidikan.

d. Menumbuhkembangkan budaya akademik di lingkungan sekolah sehingga tercipta sikap proaktif di dalam melakukan perbaikan mutu pendidikan dan pembelajaran secara berkelanjutan (sustainable).

Penelitian tindakan kelas ini dilaksanakan atas dua siklus yang secara umum menggambarkan adanya empat tahap, yaitu perencanaan (planning), tindakan (action), pengamatan (observation), dan refleksi (reflection). Agar penelitian ini terarah terhadap tujuan yang diharapkan, maka model penelitian tindakan kelas ini dilaksanakan sesuai dengan desain Penelitian Tindakan Kelas diadaptasi dari model Kemmis dan MC Taggart. Penelitian ini bertujuan untuk meningkatkan pembelajaran yang telah berlangsung, khususnya untuk meningkatkan penalaran matematis siswa. Adapun materi pembelajaran yang disampaikan dalam penelitian ini yaitu Himpunan, Himpunan bagian, Himpunan semesta, irisan dan gabungan dua himpunan, Difference (selisih), Komplemen, dan Diagram Venn.

\section{HASIL DAN PEMBAHASAN}

Penalaran Matematis 
Setelah dilaksanakan kegiatan pembelajaran dengan menggunakan model kooperatif tipe numbered head together. Dalam penalaran matematis siswa setiap siklusnya siswa mengalami peningkatan sebagaimana tampak pada tabel 1 . Hal tersebut dapat terlihat dengan meningkatnya persentase kategori siswa berdasarkan nilai tes siklus I yaitu nilai kemampuan penalaran matematis dengan sangat baik sebesar 6,06\%, kategori baik sebesar 60,60\%, kategori cukup sebesar 30,30\%, kurang sebesar 3,03\%, jelek sebesar 0\%. Dan mengalami peningkatan pada siklus II yaitu sangat baik sebesar 30,30\% baik sebesar 57,57\%, cukup sebesar 12,12\%, kurang sebesar $0 \%$, dan jelek sebesar $0 \%$.

Tabel 1. Frekuensi dan Presentase Kategori Siswa Berdasarkan

Nilai Tes Setiap Siklus

\begin{tabular}{ccccc}
\hline \multirow{2}{*}{ Kategori } & \multicolumn{2}{c}{ Siklus I } & \multicolumn{2}{c}{ Siklus II } \\
\cline { 2 - 5 } & Frekuensi & Presentase (\%) & Frekuensi & Presentase (\%) \\
\hline Sangat Baik & 2 & 6,06 & 10 & 30,30 \\
Baik & 20 & 60,60 & 19 & 57,57 \\
Cukup & 10 & 30,30 & 4 & 12,12 \\
Kurang & 1 & 3,03 & 0 & 0 \\
Jelek & 0 & 0 & 0 & 0 \\
\hline
\end{tabular}

Dengan demikian dapat dikatakan bahwa siswa dapat memahami setiap pertanyaan dan menjawabnya dengan konsep yang telah diberikan. Selain itu, tingkat penalaran ratarata siswa juga mengalami peningkatan pada setiap siklusnya melalui penerapan model pembelajaran kooperatif tipe Numbered Head Together sebagaimana tampak pada tabel 2. Pada siklus I tingkat penalaran matematis sebesar $74,54 \%$ dan pada siklus II sebesar $84,24 \%$.

Tabel 2. Rekapitulasi Tingkat Kemampuan Penalaran Matematis Siswa pada Setiap Siklus

\begin{tabular}{|c|c|c|}
\hline \multirow{2}{*}{$\begin{array}{c}\text { Tingkat Kemampuan Penalaran } \\
\text { Matematis }\end{array}$} & \multicolumn{2}{|c|}{ Siklus } \\
\hline & I & II \\
\hline Terendah & 50 & 70 \\
\hline Tertinggi & 90 & 100 \\
\hline Rata-rata & 74,54 & 84,24 \\
\hline
\end{tabular}

Tabel 3. Frekuensi dan Persentase DSK Berdasarkan Nilai Tes Siklus

\begin{tabular}{lcccc}
\hline Siklus & \multicolumn{2}{c}{ I } & \multicolumn{2}{c}{ II } \\
\hline Ketuntasan Belajar & Frekuensi & Persentase (\%) & Frekuensi & Persentase (\%) \\
\hline Tuntas & 21 & 63,63 & 29 & 87,87 \\
Tidak Tuntas & 12 & 36,36 & 4 & 12,12 \\
\hline
\end{tabular}

Untuk ketuntasan belajar klasikal dalam penelitian ini, juga mengalami peningkatan setiap siklusnya sebagaimana tampak pada tabel 3. Pada siklus I persentase daya serap klasikal siswa mencapai $63,63 \%$. Selanjutnya pada siklus II, daya serap klasikal siswa 
meningkat mencapai $87,87 \%$. Pada siklus ini terdapat 4 orang siswa yang belum tuntas, yang merupakan siswa yang sama yang tidak lulus pada siklus I dan siklus II.

Hasil analisis tersebut menunjukan bahwa pembelajaran matematika dengan menggunakan model pembelajaran kooperatif tipe NHT (Numbered Head Together) dapat meningkatkan penalaran matematis siswa. Penggunaan model pembelajaran kooperatif tipe NHT memberikan kesempatan kepada siswa untuk mengkonstruksi pengetahuan yang mereka miliki sehingga siswa lebih mudah dalam menerima dan memahami materi yang disampaikan.

\section{Respon dan Kesan Siswa}

Pembelajaran matematika dengan menggunakan respon siswa terhadap kegiatan pembelajaran dengan menggunakan model pembelajaran kooperatif tipe Numbered Head Together dapat dilihat melalui hasil analisis jurnal siswa pada setiap siklusnya. Setiap siswa memiliki komentar yang berbeda-beda terhadap pembelajaran yang telah dilaksanakan. Berdasarkan hasil analisis jurnal yang telah dilakukan diperoleh data bahwa komentar positif siswa mengalami peningkatan pada setiap siklusnya sedangkan komentar negatif mengalami penurunan sebagaimana tampak pada tabel 4. Ini berarti respon siswa terhadap pembelajaran matematika dengan menggunakan model pembelajaran kooperatif tipe Numbered Head Together dikatakan positif. Hal ini berdasarkan hasil analisis jurnal siswa yang menunjukkan peningkatan pada respon positif siswa, pada siklus I siswa yang berkomentar positif sebanyak 76\%, sedangkan pada siklus II meningkat menjadi $88 \%$. Ini menunjukkan bahwa sebagian besar siswa berkomentar positif terhadap pembelajaran matematika dengan menggunakan model pembelajaran kooperatif tipe Numbered Head Together.

Tabel 4. Frekuensi dan Persentase Jurnal Siswa

\begin{tabular}{lcccc}
\hline \multirow{2}{*}{ Kategori } & \multicolumn{2}{c}{ Siklus I } & \multicolumn{2}{c}{ Siklus II } \\
\cline { 2 - 5 } & \multirow{2}{*}{ Jumlah } & Persentase (\%) & Jumlah & Persentase (\%) \\
\hline Positif & 25 & 76 & 29 & 88 \\
Negatif & 8 & 24 & 4 & 12 \\
Jumlah & 33 & 100 & 33 & 100 \\
\hline
\end{tabular}

Sebagian siswa menyatakan ketertarikannya terhadap pembelajaran matematika dengan menggunakan model pembelajaran kooperatif tipe Numbered Head Together dengan memberi komentar bahwa dengan pembelajaran tersebut, siswa menjadi aktif 
dalam bertanya dan tidak takut lagi ketika mengerjakan soal di depan kelas. Selain itu siswa juga berkomentar bahwa dengan pembelajaran tersebut, siswa bisa bekerjasama dengan temannya dalam kelompok untuk menyelesaikan permasalahan yang diberikan. Setiap respon siswa diklasifikasikan menjadi dua jenis, yaitu respon positif dan negatif. Jurnal diisi pada setiap akhir siklus. Hasil jurnal pada setiap akhir pembelajaran sangat penting sebagai bahan masukan dari siswa untuk perbaikan pembelajaran berikutnya.

Data hasil analisis angket secara keseluruhan, disimpulkan bahwa sebagian besar siswa bersikap positif. Hal ini terbukti dari modus atau sikap yang sering muncul dari pernyataan positif siswa lebih banyak memilih Sangat Setuju (SS) dan Setuju (S), sedangkan untuk pernyataan negatif, siswa lebih banyak memilih Tidak Setuju (TS) dan Sangat Tidak Setuju (STS). Hal ini menunjukkan bahwa siswa bersikap positif terhadap pembelajaran dengan menggunakan pembelajaran kooperatif tipe Numbered Head Together.

\section{Aktivitas Guru dan Siswa}

Selain pemahaman dan respon siswa, terjadi pula peningkatan aktivitas guru dan siswa selama proses pembelajaran sebagaimana tampak pada tabel 5 dan 6 . Hal tersebut dapat dilihat dari hasil observasi yang dilakukan observer terhadap guru dan siswa yang menunjukkan adanya peningkatan setiap siklusnya.

Tabel 5. Analisis dan Pembahasan Lembar Observasi Aktivitas Guru

\begin{tabular}{ccccccccccccccc}
\hline \multirow{2}{*}{ Siklus } & Pertemuan & \multicolumn{10}{c}{ Level Aktivitas Guru } & Jumlah & $\begin{array}{c}\text { Persentase } \\
(\%)\end{array}$ \\
\cline { 2 - 10 } & 1 & 2 & 3 & 4 & 5 & 6 & 7 & 8 & 9 & 10 & 75 \\
I & 1 & 3 & 2 & 3 & 2 & 3 & 3 & 4 & 3 & 3 & 4 & 30 & 82,5 \\
\hline \multirow{2}{*}{ II } & 2 & 3 & 3 & 4 & 3 & 3 & 3 & 4 & 2 & 4 & 4 & 33 & 87,5 \\
& 1 & 3 & 4 & 3 & 4 & 3 & 3 & 3 & 4 & 4 & 4 & 35 & 95 \\
\hline
\end{tabular}

Tabel 6. Analisis dan Pembahasan Lembar Observasi Aktivitas Siswa

\begin{tabular}{|c|c|c|c|c|c|c|c|c|c|c|c|c|c|}
\hline \multirow{2}{*}{ Siklus } & \multirow{2}{*}{ Pertemuan } & \multicolumn{10}{|c|}{ Level Aktivitas Guru } & \multirow{2}{*}{ Jumlah } & \multirow{2}{*}{ Persentase $(\%)$} \\
\hline & & 1 & 2 & 3 & 4 & 5 & 6 & 7 & 8 & 9 & 10 & & \\
\hline \multirow[b]{2}{*}{ I } & 1 & 2 & 2 & 2 & 2 & 2 & 2 & 2 & 3 & 2 & 2 & 21 & 70 \\
\hline & 2 & 2 & 2 & 3 & 2 & 2 & 2 & 3 & 2 & 2 & 2 & 22 & 73 \\
\hline \multirow{2}{*}{ II } & 1 & 3 & 2 & 3 & 3 & 2 & 3 & 3 & 2 & 2 & 2 & 25 & 83 \\
\hline & 2 & 3 & 2 & 3 & 3 & 2 & 3 & 3 & 3 & 2 & 2 & 26 & 87 \\
\hline
\end{tabular}


Pengamatan observer menunjukkan bahwa guru telah cukup baik melaksanakan pembelajaran di kelas meskipun pada awal siklus masih banyak kekurangan, namun setelah dilakukan refleksi hal tersebut meningkat pada siklus berikutnya. Hal ini terbukti dari hasil analisis penilaian lembar observasi guru yang dilakukan oleh observer bahwa guru telah mencapai indikator-indikator yang diharapkan. Seperti halnya guru memberikan apersepsi dan memotivasi siswa, bertindak sebagai fasilitator, membimbing dan memberikan kesempatan kepada siswa untuk menemukan jawaban, memberikan kesempatan kepada siswa untuk mempersentasikan hasil diskusi, dan indikator-indikator lainnya yang telah dicapai oleh guru yang dapat dilihat dalam lembar observasi yang dilaksanakan setiap pertemuan pada tiap siklusnya.

\section{KESIMPULAN}

Berdasarkan hasil penelitian tindakan kelas serta pembahasan sebelumnya, melalui penggunaan model pembelajaran kooperatif tipe numbered head together sebagai upaya meningkatkan penalaran matematis pada pembelajaran matematika secara tertulis. Peneliti dapat menarik kesimpulan sebagai berikut:

1. Pembelajaran matematika dengan menggunakan model pembelajaran kooperatif tipe numbered head together dapat meningkatkan penalaran matematis. Peningkatan penalaran matematis siswa dapat dilihat pada

setiap indikator penalaran matematis siswa yang terdapat pada setiap butir soal tes siklus yang mengacu pada indikator penalaran matematis.

2. Berdasarkan hasil observasi terhadap aktivitas siswa dan guru, selama pembelajaran berjalan dengan baik sehingga siswa senang dan termotivasi dalam belajar matematika. Pembelajaran kooperatif tipe numbered head together terbukti dapat meningkatkan pembelajaran matematika di dalam kelas.

3. Respon dan sikap siswa terhadap pembelajaran kooperatif tipe numbered head together positif, yang berarti siswa menerima dengan baik dengan model pembelajaran numbered head together. Hal ini terbukti dari hasil angket siswa, wawancara dan jurnal siswa yang menunjukkan pembelajaran matematika selalu menarik dan menyenangkan. Sikap dan respon siswa merupakan salah satu potensi untuk menciptakan suasana belajar yang efektif sehingga pencapaian penalaran matematis siswa dalam pembelajaran matematika untuk dapat ditingkatkan. 


\section{DAFTAR PUSTAKA}

Arikunto, S. 2010. Prosedur Penelitian Suatu Pendekatan Praktik. Jakarta: Rineka Cipta. Aqib, Zainal. (2006). Penelitian Tindakan Kelas Untuk: Guru. Bandung: Yrama Widya. Darma, I Nyoman. et al. (2013). Pengaruh Pendidikan Matematika Realistik Terhadap Pemahaman Konsep dan Daya Matematika Ditinjau dari Pengetahuan Awal Siswa SMP Nasional Plus Jembatan Budaya. Dalam e-journal Program Pascasarjana Universitas Pendidikan Ganesha [online]. Tersedia: file:///c:/users/acer/download/12-906-1-SM.pdf [07 Juni 2016]

Dewi, Fanny Utari. (2009). Pengaruh Penerapan Matematika Realistik Terhadap Peningkatan Penalaran Siswa SMA. (Skripsi). Cianjur: UNSUR (tidak diterbitkan)

Putri, Finola Marta. (2013). Pengaruh Pembelajaran Matematika Realistik Terhadap Kemampuan Penalaran Matematis Siswa SMP. Dalam Edumatica [online], volume 03,19-26 Tersedia:http://download.portalgaruda.org/article.php?=144681\&val=870 [07 Juni 2016]

Sadulloh, Uyoh. (2007). Pengantar Filsafat Pendidikan. Bandung: Alfabeta.

Undang-undang Republik Indonesia Nomor 20 Tahun 2003 tentang SISDIKNAS. 2010. Bandung: Citra Umbara. 